\section{Car maker joins exodus from anti-Kyoto coalition}

\section{Washington}

The US company General Motors (GM)

last week became the third major automobile manufacturer to withdraw from a lobbying group that has been leading opposition to the 1997 Kyoto Protocol, an accord designed to reduce global warming.

The move brings to five the number of large corporations that have recently resigned from the Global Climate Coalition (GCC), an 11-year-old industry coalition that vigorously opposes the Kyoto Protocol.

GM told the group last week that it was not renewing its membership. Its withdrawal follows that of Ford in December and DaimlerChrysler in January. The oil company Texaco and The Southern Company, a large US power company, have also recently resigned (see Nature 404, 118; 2000.)

In response, the GCC announced that it would no longer allow individual companies as members, but only trade associations, cutting its membership from 50 to 14. "We wanted to take this membership issue... out of the lexicon," says Frank Maisano, a GCC spokesman. "It's a distraction from the real debate."

Mia Walton, a spokeswoman for GM, says that GM's move reflects a desire "to take a global, holistic, more 'GM' approach to the issue" of climate change. "The Global Climate Coalition has tended to be a North American or USfocused entity," she says. GM has plants in 53 countries and sells products in over 200. Walton adds that GM's opposition to the Kyoto Protocol still stands. Like the GCC, the company opposes the treaty's binding targets and timetables, and objects to the fact that it does not require participation on the same terms by all countries.

Some observers say that the corporations' withdrawals may simply reflect the lower prospects of ratification of the Kyoto Protocol by the US Senate. And with little prospect of ratification imminent, it is said, the companies can afford to polish their public images by withdrawing from GCC.

Whatever the motivation, the move appears to have weakened the GCC. Other major companies have left the lobby group in the past. In 1998, the British/Dutch oil company Shell withdrew, and in 1996, BP did the same (see Nature 392, 856; 1998 and 383, 470; 1996.)

\title{
Could AIDS treatments slip through patents loophole?
}

Washington

A controversial patent issued last month on the gene for a key HIV target protein might not have been approved under recently revised patent guidelines.

These may open a loophole allowing companies to develop anti-AIDS drugs using the target protein, CCR5, without paying licence fees to the patent-holder, Human Genome Sciences (HGS) Inc. of Rockville, Maryland. But it is not yet clear whether the new guidelines - reflecting Washington's shifting perceptions about the use of patent law in this area - would apply, since the application was probably examined before they took effect.

The patent award continues to upset the researchers who characterized CCR5 in 1996 and showed for the first time that it is required for efficient HIV replication. They believe that they — and not HGS - should hold the rights to the chemokine receptor as a potential AIDS drug target.

When HGS filed the patent on the gene for CCR5 in 1994, the company had no idea of the gene's role in HIV, and was expecting instead to exploit the patent primarily in the development of anti-inflammatory therapy.

Gene patent rules have tightened up considerably since then. Applicants must now demonstrate "specific and substantial utility" (see Nature 403, 3, 2000).

William Haseltine, HGS's chief executive officer, says that the company's CCR5 patent meets all the new criteria for exploitation in the anti-inflammatory area, which is specifically mentioned in the patent. But he admits that AIDS therapeutics is "another question".

HGS expects that prospective drug developers wishing to exploit CCR5 to treat AIDS will have to pay the company a licence fee. But some companies may not follow this practice.

Schering-Plough has already shrugged off HGS's intellectual property claim, having started developing a small CCR5-binding molecule before HGS's patent was approved. "Right now, their patent has no bearing on our compound," says spokesman Robert Consalvo. The company does subscribe to HGS's gene and protein databases. If it used that information to modify its drug, Schering-Plough would have to pay HGS royalties if the drug reached the market.

Haseltine points out that the scientists can make their own patent claims. Any additional patent approved by the US Patent and Trademark Office could complement the HGS patent, he says, hinting that drug developers might then have to 'cross-license', or pay two separate entities to work on one drug target.

Ned Landau, now an associate professor at the Salk Institute, was a member of one of five groups who raced to publish papers characterizing CCR5 in 1996. He and other researchers are also upset that HGS filed its patent primarily on the basis of computational searches, rather than experimental work.

"We did a lot of work," Haseltine says in reply, pointing out that computational searches involve making a large collection of human messenger RNA, conducting homology searches for existing genes, then focusing on specific families of proteins of potential interest to pharmaceutical partners.

Haseltine says that the company will not enforce its patent claim on academic researchers. HGS holds 114 gene patents, and has filed about 2,750 more. Paul Smaglik

\section{Israeli R\&D grants 'too restrictive'}

\section{Jerusalem}

The Israeli government should attach fewer strings to research and development grants, says a new report.

Tel Aviv University economist Manuel Trajtenberg submitted his report last week to the Office of the Chief Scientist of the Ministry of Industry and Commerce. Small and medium-sized high-tech firms should be given preference over large ones, he says, and successful companies should not have to reimburse the government. He suggests scrapping the requirement for companies receiving government $R \& D$ funds to produce any resulting goods in Israel.

Trajtenberg also recommends expansion of the chief scientist's 'Magnet' programme funding cooperation between private companies and academic institutions. This would, he believes, counter the trend of small start-ups selling their technology abroad.

The report has been welcomed in Israel's high-technology community, though there is some scepticism about whether its advice is likely to be implemented.

Yossi Sela, managing partner at venture capital group the Gemini Fund, notes that many small companies don't even apply for government funds because of the restrictions and conditions. He points out that Israel's strength is not in cheap production but rather in the technology itself. Haim Watzman 